Jurnal Ilmu Sosial dan Pendidikan (JISIP)

Vol. 5 No. 3 Juli 2021

Terakreditasi Peringkat 5 (No. SK: 85/M/KPT/2020)

e-ISSN : 2656-6753, p-ISSN: 2598-9944

DOI: 10.36312/jisip.v5i3.2212 /http://ejournal.mandalanursa.org/index.php/JISIP/index

\title{
Relevansi Birokrasi Rational Weber Dalam Upaya Percepatan Pembangunan Daerah Perbatasan Kabupaten Belu
}

\author{
Adeo Dato J Barros Mbiri' ${ }^{1}$, Dedi Supriadi \\ ${ }^{1}$ Dosen Ilmu Pemerintahan STISIP Fajar Timur Atambua \\ ${ }^{2}$ Dosen Ilmu Pemerintahan Institute Ilmu Social dan Ilmu Budaya Samawa Rea
}

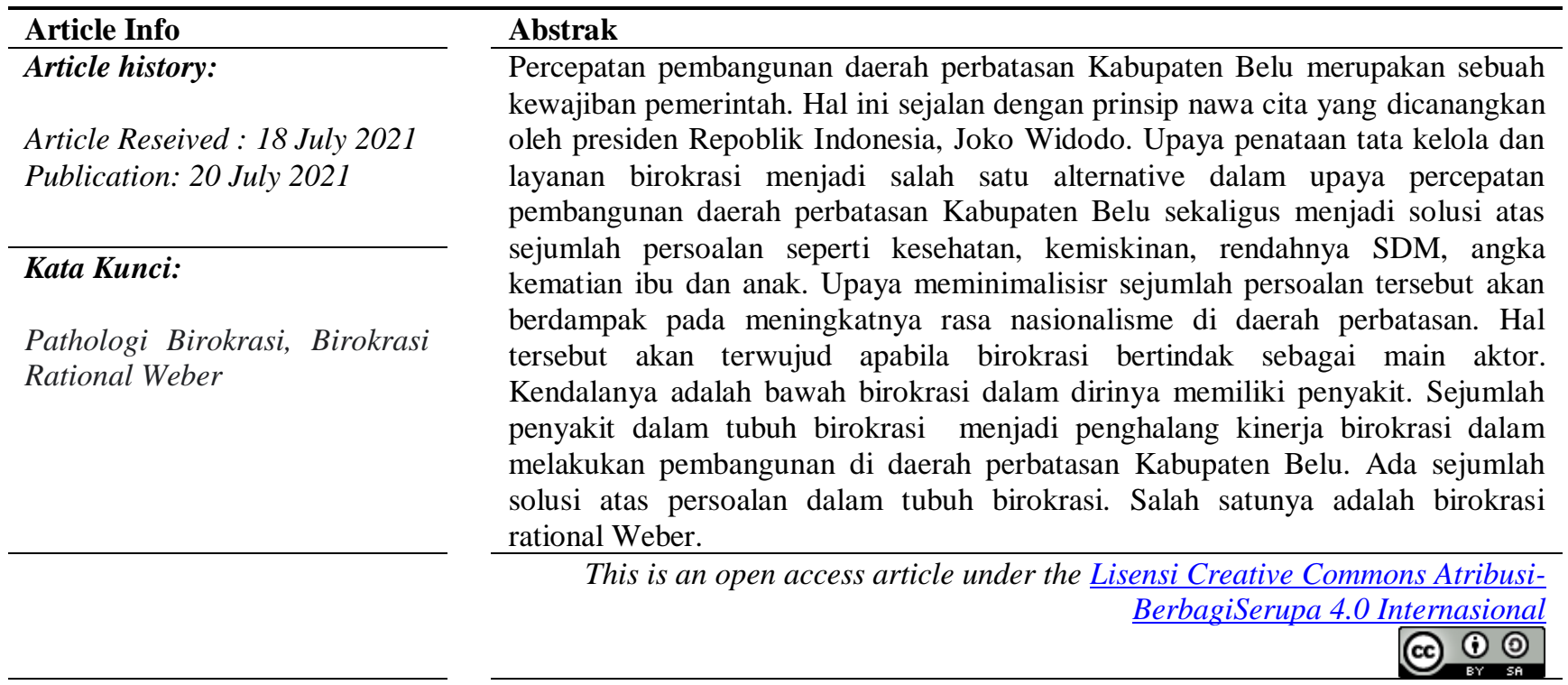

Corresponding Author:

Adeo Dato J Barros Mbiri

Dosen Ilmu Pemerintahan STISIP Fajar Timur Atambua

Email:adeombiri@gmail.com

\section{PENDAHULUAN}

Percepatan pembangunan daerah perbatasan merupakan suatu tanggungjawab pemerintah. Hal ini tertuang dalam visi dan misi pemerintahan Joko Widodo periode 2014-2019, dalam program nawa cita point tiga yakni 'membangun Indonesia dari pinggiran dengan memperkuat daerahdaerah dan desa dalam kerangka negara kesatuan'. Percepatan pembangunan juga merupakan salah satu manivestasi dari tujuan negara yang tertuang di dalam alinea ke IV UUD1945.

Kabupaten Belu sebagai salah satu daerah pinggiran/perbatasaan telah mendapatkan sentuhan dari pemerintah pusat maupun pemerintah daerah Kabupaten Belu untuk mendorong percepatan pembangunan pada berbagai bidang yakni pembangunan infrastruktur, penataan birokrasi dan pelayanan public, serta pembangunan sumber daya manusia. Pembangunan infrastruktur oleh pemrintah pusat berupa pembangunan pos lintas batas Motaain, jalan sabuk merah, Bendungan Roti Klot, pembangunan ruas jalan negara. Penataan birokrasi dan layanan public dapat dilihat dalam bentuk pembangunan plaza pelayanan public. Pembangunan sumber daya manusia melalui pendidikan formal yakni pembangunan Universitas Pertahanan. Pembangunan sumber daya 
manusia melalui pendidikan non formal dilakukan melalui pelatihan dan kursus, kelompok tenun, kelompok daur ulang sampah dan lain-lain.

Upaya pemerintah dalam melakukan pembangunan di daerah perbatasan Kabupaten Belu patut diapresiasi, tetapi data menunjukan bahwa hasil pembangunan belum optimal. Kurang optimalnya hasil pembangunan di Kabupaten Belu dapat dilihat dalam sejumlah permasalahan sebagai berikut: angka kematian ibu dan anak berdasarkan data yang di dapat dari dinas Kesehatan kabupaten belu, pada tahun 2016 terdapat 4 kasus kematian, 2017 terdapat 6 kasus dan di tahun 2019 kematian bayi berjumlah 71 orang dan ibu 5 orang. Jumlah bayi gizi buruk dari jumlah 14.000 balita di kabupaten Belu, terdapat 3.900 balita yang terpapar gizi buruk dengan kategori bayi yang pendek dan sangat pendek berdasarkan riskesdas.Rendahnya kualitas guru di Kabupaten Belu sebagaimana tercatat 1.600 guru di belu yang belum mendapatkan gelar pendidikan strata 1 (S1) padahal gelar strata 1 sebagai salah satu persayaratan seseorang menjadi guru.

Rendahnya hasil pembangunan di daerah perbatasan Kabupaten Belu dipengaruhi oleh berbagai faktor. Salah satu faktor yang turut berpengaruh adalah rendahnya layanan birokrasi sebagai aparatur pemerintah dalam menghadirkan layanan public. Kehadiran birokrasi sebagai aparatur yang menghadirkan secara langsung layanan pemerintah dalam bentuk administrasi, barang dan jasa sering menghadirkan persoalan dalam sikap memberikan layanan seperti kurang disiplin, tidak bersikap rational dan proporsional, impersonal, layanan yang lamban, apatis, gagap teknologi, sistem yang kaku dan lain-lain. Layanan birokrasi yang mengandung penyakit memperngaruhi hasil pembangunan yakni menciptakan persoalan social sebagaigaimana disebutkan di atas.

Hal ini mendorong peneliti untuk melakukan penelitian tentang pengaruh birokrasi dalam mendorong percepatan pembangunan di daerah pinggiran khususnya daerah perbatasan Kabupaten Belu. Konsentrasi penelitian ini adalah birokrasi sebagai aparatur yang menghadirkan pelayanan kepada masyarakat dengan mengacu pada birokrasi rational Max Weber

\subsection{Rumusan masalah}

Rumusan masalah dalam penelitian ini adalah permasalahan-permasalahan yang terdapat dalam birokrasi pemerintah daerah Kabupaten Belu

\section{METODE PENELITIAN}

Penelitian ini menggunakan metode kualitatif. Sampel dalam penelitian ini adalah birokrasi di Kabupaten Belu. Teknik pengumpulan data adalah melalui observasi dan wawancara. Penulis melakukan analisis data berdasarkan fakta riil di lapangan dan menganalisisnya berdasarkan teori birokrasi rational Weber.

\section{HASIL DAN PEMBAHASAN}

\subsection{Karangka Pikir Birokrasi Weber}

Birokrasi menurut Weber adalah metode organisasi terbaik dengan spesialiasasi tugas. Weber mengemukakan tiga tipologi birokrasi yakni legitimasi karismatik, legitimasi tradisional dan legitimasi rational.

Weber merumuskan beberapa hal sebagai sebuah pra syarat birokrasi sebagai seorang aparatur pemerintah sebagai berikut: 1) Kerja ketat pada peraturan (rule) 2) Tugas khusus (spesialisasi) 3) Kaku dan sederhana (zakelijk) 4) Penyelenggaraan secara resmi (formal) 5) Pengaturan dari atas ke bawah (hierarkis), 6) Pembuatan dan pengambilan keputusanBerdasarkan logika (rasional), 7) Terpusat (berdasarkan otoritas)8) Taat dan patuh (obedience) 9) Disiplin (dicipline) 10) Terstruktur atausistematis 11) Tidak pandang bulu (impersonal)

Pembangunan daerah perbatasan membutuhkan sinergi dari berbagai elemen baik politik, birokrasi, ekonomi, teknologi, pertanian, peternakan, infrastruktur dan lain-lain. Salah satu elemen yang sangat urgen adalah birokrasi. Birokrasi yang dimaksud adalah sekelompok orang 
yang berkerja pada kantor pemerintahan (Albrow). Tujuannya adalah menghadirkan layanan kebutuhan masyarakat dalam bentuk administrasi, barang dan jasa.

\section{HASIL PENELITIAN DAN PEMBAHASAN}

\subsection{Pathologi Birokrasi Kabupaten Belu}

Persoalan yang ditemukan dalam layanan birokrasi yang menghambat adanya gerak pembangunan di daerah perbatasan Kabupaten Belu adalah sikap layanan birokrasi. Sikap prilaku birokrasi dalam memberikan layanan (social action) menurut Weber: affective, traditional, value rational and instrumentally rational. (Setiyono, 2004: 47-49).

Sikap prilaku layanan birokrasi sebagaimana disebutkan di atas menimbulkan berbagai persoalan di Provinsi Nusa Tenggara Timur sebagai salah satu provinsi perbatasan (daerah $3 \mathrm{~T}$ ) dan juga Kabupaten Belu sebagai kabupaten yang berbatasan langsung dengan negara Demokratik Timor Leste. Fakta yang dapat diamati adalah tingginya angka kemiskinan, rendahnya pembangunan indeks kemanusiaan, Persoalan kesehatan, rendahnya daya serap anggaran, rendahnya pembangunan infrastruktur, rendahnya pertumbuhan ekonomi.

Pemicu terjadinya sejumlah persoalan di atas salah satunya adalah sikap layanan birokrasi di Kabupaten Belu. Sikap layanan birokrasi yang tidak sehat yang membuat birokrasi berpenyakit (bureau pathologi)/pathologi birokrasi adalah sikap afektif, tradisional, impersonal, dan formalitas. Sikap afektif sering dijumpai dalam bentuk layanan birokrasi berdasarkan pada sikap rasa, rasa suka karena satu klan, rasa segan karena keluarga pimpinan, rasa simpati karena satu pilihan politik, rasa antipati karena lawan politik. Layanan sering diberikan tanpa pertimbangan rational, berdasarkan aturan dan prosedur. Layanan berdasarkan pada sikap afektif membuat birokrasi tampil sebagai tuan atau budak.

Sikap tradisonal yang dimaksud adalah sikap layanan birokrasi yang dijalankan secara terus menerus sehingga membudaya walaupun tidak rational. Ciri yang dapat diamati adalah, hormat secara berlebihan pada atasan sehingga menempatkan atasan sebagai pihak yang selalu benar, sikap menerima apa adanya walaupun keputusan yang dikeluarkan tidak dapat dipertanggungjawabkan secara rational seperti sikap balas jasa, sikap atur damai.

Sikap impersonal merupakan sikap tidak membedakan urusan pribadi dengan urusan public. Persoalan pribadi di keluarga, masyarakat berlanjut pada urusan pelayanan. Birokrasi cenderung menghambat pelayanan karena persoalan hubungan pribadi yang renggang, pilhan politik dan lain-lain. sikap impersonal ini hampir sejalan dengan sikap mix yang dikemukankan oleh Riggs; birokrasi tidak membedakan mana urusan pribadi dengan urusan kantor. Barang kantor dibawa ke rumah, barang kantor digunakan untuk kepentingan kelompok, pribadi, keluarga dan lain-lain.

Sikap formalitas yakni sikap lebih mengutamakan urusan formal seperti upacara dan mengesampingkan kinerja. Waktu dan tenaga dan perhatian birokrasi lebih dialokasikan pada upacara dan kegiatan formal daripada kerja nyarrta. Hal ini jelas mempengaruhi lajunya pertumbuhan pembangunan disegala dbidang di wilayah kabupaten Belu.

Sejumlah sikap birokrasi yang menghambat layanan public dalam bentuk administrasi, barang dan jasa sebagai penyakit birokrasi (bureau pathologi/pathologi birokrasi) di Kabupaten Belu menjadi persoalan yang perlu sentuhan dari bidang ilmu. Jalan keluar yang dapat dietempuh adalh menerapkan birokrasi rational Weber. Birokrati ratioanal Weber yang ditawarkan peneliti adalah beberapara buah pikiran Weber yang dianggap relevan. Peneliti tidak mengutip semua buah pikiran Weber tentang birokrasi tetapi penulis hanya mengambil beberapa buah pikiran yang dapat berguna untuk menjawabi persoalan pathologi birokrasi di Kabupaten Belu.

Berdasarkan hasil pengamatan penulis dilapangan pada beberapa instansi pemerintahan Kabupaten Belu penulis menemukan adanya sejumlah prilaku birokrasi yang tidak sejalan 
dengan apa yang digariskan weber. Beberapa hal yang paling mencolok adalah pada point 'berdasarkan logika, disiplin dan impersonal'. Kerja birokrasi masih mengedapankan kekuasaan. Pemeberian layanan masih bersifat tradirional. Pimpinan ditempatkan sebagai pribadi yang selalu benar, anti kritik, dan menjadi tolak ukur dalam layanan. Maksud pimpinan menjadi tolak ukur dalam layanan adalah segala keputusan tidak berdasarkan pada aturan, kesepakatan tetapi disesuaikan dengan waktu pimpinan.

Pada point disiplin, dapat diamati melalui masuk kantor dan meningggalkan kantor pada waktunya, yakni berdasarkan aturan jam kantor yang telah ditetapkan, mebutamakan pelayanan pada jam kantor. Fakta yang ditemukan adalah para pegawai sering terlambat, meninggalkan kantor lebih awal untuk urusan pribadi. Point impersonal (tanpa pandang bulu) pelayanan masih berpihak kepada kedekatan suku, hubungan keluarga dan kedekatan pribadi.

Sikap birokrasi dalam memberikan layanan kepada masyarakat tidak dilandasi pertimbangan rational. sikap yang muncul adalah sikap affektif. Affective merupakan perilaku atau tindakan yang dikendalikan oleh emosi. Apabila birokrasi dihadapkan pada tuntutan pelayanan maka sikap yang ditujukan adalah luapan kemarahan, emosi, kesedihan. Hal yang dapat diamati adalah apabila birokrat sedang dalam suasana gembira maka segala layanan akan mudah dan cepat. Tetapi apabila birokrat sedang dalam suasana sedih atau marah karena persoalan tertentu maka pelayanan akan menjadi rumit. Bahkan masyarakat disuruh pulang tanpa dilayani.

Permasalahan lain dalam prilaku birokrasi di Kabupaten Belu dalam birokrasi adalah prilaku tradisional. Sikap tradisional atau traditional action adalah tindakan yang dilakukan karena mengikuti tradisi atau kebiasaan-kebiasaan yang dilakukan oleh orang-orang terdahulu. Kebiasaan dalam kehidupan masyarakat secara tidak langsung seringkali menjadi pedoman yang kurang disadari. Apalagi kebiasaan-kebiasaan itu sudah melembaga, diyakini dan dijalankan secara rutin oleh masyarakat. Akibatnya kesa;ahan yang sama dilakukan secara berulang dan diwariskan. Layanan pada birokrasi sulit berubah, lamban dan tidak up date

Sikap prilaku birokrasi yang tidak rational dalam memberikan layanan public menjadikan birokrasi Kabupaten Belu sebagai sebuah organisasi pemerintahan yang dibenci dan dirindu. Birokrasi dirindu masyarakat karena birokrasi merupakan condition sine qua non, sesuatu yang mutlak ada, demi menghadirkan pelayanan public. Tetapi disatu sisi birokrasi dibenci karena sikap dalam memberikan layanan yang dijalankan oleh birokrasi tidak sesuai harapan masyarakat. Birokrasi mengandung penyakit di dalam dirinya yang disebut dengan bureaupathologi (patologi birokrasi) ciri yang dapat diamati adalah impersonal, menjadi alat politik, tidak berdasarkan pada hukum, aturan dan prosedur.

Munculnya pathologi birokrasi dalam layanan public menghambat percepatan pembangunan, kepercayaan masyarakat kepada pemerintah melalui aparaturnya, sikap apatis, rendahnya partisipasi masyarakat dalam pembangunan negara. hal ini memunculkan persoalan social seperti tingginya anggka gizi buruk, stunting, kematian ibu dan anak dan lain-lain.

\section{SIMPULAN}

Weber mengemukakan tiga tipologi birokrasi yakni tipologi karismatik, tipologi tradisional dan tipologi rational. dari ketiga tipologi birokrasi di atas tipologi birokrasi rational dianggap sebagai tipologi birokrasi yang paling ideal uantuk pembangunan sebuah negara. Kritik yang sering dilontarkan oleh para pemerhati ilmu birokrasi lainnya adalah tipologi birokrasi rational dianggap rumit dan sulit dicapai. Tetapi pada prinsipnya tipologi ini dijadikan sebagai alat ukur dan patokan untuk pembangunan daerah perbatasan kabupaten belu pada khusunya dan bangsa inonesia pada umunya. 


\section{DAFTAR PUSTAKA}

Belukab.go.id timexkupang.com 15/02/21www.nttonlinenow.com 2020/11/05

Dwiyanto, Agus Dkk. 2002 Reformasi Birokerasi Publik di Indonesia. Yogyakarta: Pusat studi Kependudukan dan Kebijakan Universitas Gadjah Mada .

Fukuyama, Francis 2005 memperkuat Negara: Tata Pemerintahan dan tata dunia Abad 21, Jakarta: PT Gramedia Pustaka Utama.

Hamirul, 2017, Patologi Birokrasi Yang Dimanifestasikan Dalam Perilaku Birokrat Yang Bersifat Disfungsional Otoritas:Jurnal Ilmu Pemerintahan7(1),April 2017,

http://www.nttonlinenow.com/new-2016/2019/02/07/tiga-tahun-terakhir-angka-kematian-ibu-danbayi-di-belu-meningkat/

https://regional.inews.id/berita/jalan-lintas-timor-tertimbun-longsor-warga-belu-terisolasi

https://www.antaranews.com/berita/991788/pemkab-belu-segera-tangani-3900-anak-terkena-giziburuk

https://www.cnnindonesia.com/nasional/20150529182621-20-56604/ribuan-guru-di-belu-belumbergelar-sarjana

Osborne, David and Peter Plastrik. 1992. Banisbing Bureaucracy, New York: Addison wesley PuBLISING Company, inc.

Riggs, Fred W.1996. Administrasi Negara-negara Berkembang Teori Masyarakat Transisi, judul aslinya Administration in developing countries, diterjemahkan ke dalam bahasa Indonesia oleh Tim Penerjamaah YosagamaJakarta,PT.Raja GrafindoPersada,1996

Triantoro, Bambang Wicaksono, Citizen Charter dan Reformasi Birokrasi,Jurnal Kebijakan dan Administrasi Publik, Vol.8 No.2, November 2004. 